\title{
MUTU CABAI RAWIT (CAPSICUM FRUTESCENS L) PADA TINGKAT KEMATANGAN DAN SUHU YANG BERBEDA SELAMA PENYIMPANAN
}

\author{
Desi Natalia Edowai ${ }^{1}$, Stella Kairupan ${ }^{2}$ dan Handry Rawung ${ }^{2}$ \\ ${ }^{1}$ Jurusan Teknologi Pertanian, Fakultas Teknologi Pertanian, Universitas Papua, \\ Korespondensi :Jl.Gunung Salju Amban Manokwari-98314 Papua Barat \\ Email: brightlight.natalia@yahoo.co.id \\ ${ }^{2}$ Jurusan Teknologi Pertanian, Fakultas Pertanian, Universitas Sam Ratulangi \\ Korespondensi : Kampus Unsrat, Bahu Manado - 95115 Sulawesi Utara
}

\begin{abstract}
The objective of this study is to know the ripeness level of small chilli and the right temperature during storage as far as the quality of small chilli can to defend until marketing. The study was conducted at the laboratory of Physiology and Postharvest and laboratory of Food Science and Technology of Research in Agriculture Faculty of Sam Ratulangi University Manado. Three level of ripeness are green ripe, green reddish ripe and red ripe. Temperature of storages are storage in room temperature $28^{\circ} \mathrm{C}-32^{\circ} \mathrm{C}(64-77 \%)$, $4^{\circ} \mathrm{C}-10^{\circ} \mathrm{C}(90-95 \%), 4^{\circ} \mathrm{C}-(-22)^{\circ} \mathrm{C}(95-98 \%)$, and $-10^{\circ} \mathrm{C}(99 \%)$. With long storage are 30 days. The Method of analyzed study result is descriptive analysis and the data are presented by the table. The quality of small chilli during storage looked about the height of water, weight, the height of capsaicin, and colour. The right temperature and the right ripeness can to maintain quality of small chilli until storage. The result study show is in level ripeness green ripe and green reddish ripe and than storage temperature $4{ }^{\circ} \mathrm{C}-10^{\circ} \mathrm{C}(90-95 \%)$ can maintain the qualiy of small chilli during storage. It is looked from amount of the height of water, weight, the height of capsaicin, and colour during storage always increase regulary.
\end{abstract}

\section{Key Words : quality of small chilli, ripeness level and storage temperature}

\section{PENDAHULUAN}

Cabai rawit (Capsicum frutescens L.) merupakan salah satu tanaman hortikultura dari famili Solanaceae yang tidak saja memiliki nilai ekonomi tinggi, tetapi juga karena buahnya yang memiliki kombinasi warna, rasa, dan nilai nutrisi yang lengkap (Kouassi et al, 2012). Cahyono (2003) mengemukakan bahwa tanaman ini termasuk tanaman semusim atau tanaman berumur pendek yang tumbuh sebagai perdu atau semak, dengan tinggi tanaman dapat mencapai $1,5 \mathrm{~m}$. Menurut Endjang S \& Meksy D (2015), produksi buah dipengaruhi oleh tinggi tanaman (92\%), diameter buah (89\%), dan panjang buah (78\%), dengan demikian, semakin tinggi tanaman maka produksi buah akan semakin meningkat. Ketika produksi meningkat, maka mutu cabai rawit harus dipertahankan.

Cabai rawit memiliki karakteristik tersendiri sebagai mutu yang harus dipertahankan. Standar mutu cabai rawit dapat mengacu pada Standar Nasional Indonesia (SNI 01-4480-1998) yang dapat dilihat pada Tabel.1, namun untuk keragaman ukuran, cabai rawit yang kecil-kecil memiliki ukuran antara $2-2,5 \mathrm{~cm}$ dan lebar $5 \mathrm{~mm}$, sedangkan cabai rawit agak besar memiliki ukuran panjang mencapai $3,5 \mathrm{~cm}$ dan lebar mencapai $12 \mathrm{~mm}$ (Cahyono, 2003). 
Tabel.1 Kualitas Cabai merah besar segar berdasarkan Standar Nasional Indonesia (SNI 01-4480-1998)

\begin{tabular}{|c|c|c|c|c|}
\hline \multirow{2}{*}{ NO } & \multirow{2}{*}{ Jenis Uji } & \multicolumn{3}{|c|}{ Persyaratan } \\
\hline & & Mutu I & Mutu II & Mutu III \\
\hline 1 & Keseragaman warna & $\begin{array}{c}\text { Merah > } \\
95 \%\end{array}$ & $\begin{array}{r}\text { Merah } \geq \\
95 \%\end{array}$ & $\begin{array}{c}\text { Merah } \geq \\
95 \%\end{array}$ \\
\hline 2 & Keseragaman & $\begin{array}{c}\text { Seragam } \\
(98 \%)\end{array}$ & $\begin{array}{c}\text { Seragam } \\
(96 \%)\end{array}$ & $\begin{array}{c}\text { Seragam } \\
(95 \%)\end{array}$ \\
\hline 3 & \multirow{2}{*}{$\begin{array}{l}\text { Bentuk } \\
\text { Keragaman Ukuran }\end{array}$} & 98 Normal & 96 Normal & 95 Normal \\
\hline \multirow[t]{7}{*}{4} & & & & \\
\hline & \multicolumn{4}{|l|}{ a. Cabai Merah Besar } \\
\hline & - $\quad$ Panjang buah & $12-14 \mathrm{~cm}$ & $9-10 \mathrm{~cm}$ & $<9 \mathrm{~cm}$ \\
\hline & $\begin{array}{ll}\text { - Garis tengah } \\
\text { pangkal }\end{array}$ & $1,5-1,7 \mathrm{~cm}$ & $1,3-1,5 \mathrm{~cm}$ & $<1,3 \mathrm{~cm}$ \\
\hline & \multicolumn{4}{|l|}{ b. Cabai Merah Kecil } \\
\hline & Panjang buah & $>12-17 \mathrm{~cm}$ & $>10-12 \mathrm{~cm}$ & $<10 \mathrm{~cm}$ \\
\hline & $\begin{array}{l}\text { - Garis Tengah } \\
\text { Pangkal }\end{array}$ & $>1,3-1,5 \mathrm{~cm}$ & $>1,0-1,3 \mathrm{~cm}$ & $<1,0 \mathrm{~cm}$ \\
\hline 5 & Kadar kotoran & 1 & 2 & 5 \\
\hline \multirow[t]{3}{*}{6} & \multicolumn{4}{|l|}{ Tingkat Kerusakan dan busuk } \\
\hline & Cabai merah besar & 0 & 1 & 2 \\
\hline & Cabai merah kerinting & 0 & 1 & 2 \\
\hline
\end{tabular}

Sumber : Departemen Pertanian, Standar Mutu Indonesia SNI 01-4480-1998

Karakteristik yang menonjol pada cabai rawit yaitu zat capsaicin yang membuat rasa pedas. Selain itu, yang tidak kalah penting adalah tekstur dan warna dari cabai rawit. Cabai mengandung $0,1-1 \%$ rasa pedas, yang disebabkan oleh kandungan zat capsaicin (Cahyono, 2003).

Cabai rawit setelah panen masih melakukan aktifitas hidup seperti respirasi. Respirasi dapat diuraikan sebagai pemecahan oksidatif dari bahan - bahan yang kompleks yang biasanya terdapat di dalam sel seperti zat pati, asam - asam organik, dan lain-lain menjadi molekul - molekul yang lebih sederhana seperti $\mathrm{CO}_{2}$ dan $\mathrm{H}_{2} \mathrm{O}$ (Apandi, 1984). Selain mengalami proses respirasi, setelah dipanen cabai rawit akan mengalami pelayuan akibat adanya proses transpirasi. Oleh karena itu, untuk mempertahankan mutu cabai rawit dari produsen sampai pada konsumen diperlukan penanganan pascapanen. Penanganan pascapanen yang penting untuk mempertahankan mutu cabai rawit adalah dengan pengemasan dan penyimpanan. Tjiptono \& Diana (1995) dalam Djumali M \& Sailah I (2005) mengungkapkan bahwa pengertian mengenai mutu dapat dipahami sebagai usaha untuk memenuhi harapan pelanggan mencangkup produk, jasa, proses, dan lingkungan sesuai dengan kondisi yang selalu berubah.

Perlakuan seperti penyimpanan dan Pengemasan perlu dilakukan untuk mempertahankan mutu. Pegemasan dilakukan sebelum pemasaran dan bertujuan untuk mencegah kerusakan produk. Cabai rawit biasanya dikemas dengan menggunakan plastik polietilen karena memiliki sifat kedap air dan uap air, serta murah dan mudah didapat. Penyimpanan menurut Syarief \& Halid (1992) adalah suatu tindakan pengawetan bahan pangan dan pakan yang dimaksudkan untuk memperpanjang daya simpan agar dapat dikonsumsi pada waktu yang akan datang dengan mutu yang tetap baik. Cabai rawit dapat disimpan pada lemari pendingin, suhu ruang, dan kontrol atmosfir.

Penyimpanan dingin atau pendinginan merupakan proses pengambilan panas dari produk pangan sehingga suhu produk menjadi $1-8^{\circ} \mathrm{C}$ dan proses pembekuan suhu diturunkan sampai di bawah 
$0^{\circ} \mathrm{C}$ (Estiasih \& Ahmadi, 2009). Menurut Asgar (2009), pendinginan bertujuan menekan tingkat perkembangan mikroorganisme dan perubahan biokimia. Penurunan suhu dalam penyimpanan, pada umumnya baik untuk memperpanjang daya simpan cabai rawit. Suhu yang rendah dapat memperlambat aktifitas fisiologis dari cabai rawit.

kematangan $\begin{gathered}\text { Selain suhu, tingkat } \\ \text { cabai rawit juga akan }\end{gathered}$ berpengaruh selama penyimpanan, makin matang cabai rawit makin peka terhadap kerusakan dingin. Tingkat kematangan salah satunya dapat dilihat dari perubahan warna, dan warna berpengaruh terhadap mutu.

Oleh karena itu, perlu diadakan penelitian tentang pengaruh suhu dan tingkat kematangan selama penyimpanan cabai rawit yang dikemas pada plastik polietilen. Penelitian ini bertujuan untuk mengetahui tingkat kematangan yang tepat dan suhu yang tepat selama penyimpanan sehingga mutu cabai rawit dapat dipertahankan.

Hasil penelitian ini diharapkan dapat memberikan informasi tentang suhu yang tepat pada tingkat kematangan cabai rawit selama penyimpanan sehingga cabai rawit dapat disimpan lebih lama sebelum dipasarkan.

\section{METODE}

\section{Bahan}

Bahan yang digunakan adalah adalah cabai rawit hijau $\pm 30 \mathrm{~kg}$, dengan tingkat kematangan muda (cabai rawit berwarna hijau) yang dipanen 45 HST (Hari Setelah Tanam), setengah matang (cabai rawit berwarna hijau kemerah-merahan) yang dipanen 55 HST dan matang (cabai rawit berwarna merah) yang dipanen 65 HST. Plastik Polietilen 0,03 mm. Bahan kimia yang digunakan untuk menentukan kadar capsaicin dan warna yaitu etanol dan aseton.

Alat

Alat yang digunakan antara lain :lemari pendingin, termometer, RH meter, oven listrik, loyang plastik, aluminium foil, desikator, labu ukur, spatula, penggiling (grinder), mortar, timbangan analitik, spektrofotometer, sealer, dan alat tulis menulis.

\section{Prosedur Penelitian}

Prosedur dalam penelitian yang dilakukan adalah sebagai berikut: Cabai yang diperoleh dari petani sesuai dengan 3 tingkat kematangan dicuci bersih lalu dikeringanginkan. Cabai rawit ditimbang sebanyak $1 / 2 \mathrm{~kg}$ untuk setiap perlakuan, kemudian dimasukan ke dalam plastik polietilen $0,03 \mathrm{~mm}$ dengan lubang ventilasi $0,5 \mathrm{~cm}$ dan jarak antar lubang ventilasi $8 \mathrm{~cm}$ yang kemudian diseal. Cabai rawit yang dikemas kemudian disimpan pada suhu ruang dan lemari pendingin dengan suhu $4-10{ }^{\circ} \mathrm{C}$. Penyimpanan dilakukan selama 30 hari. Kadar air, kadar capsaicin dan bobot cabai rawit diukur kemudian Warna ditentukan dengan menggunakan alat spektofotometer. Pengukuran suhu dan RH ruang penyimpanan dilakukan setiap hari. Pengamatan dan pengukuran selanjutnya dilakukan setiap 6 hari selama penyimpanan.

\section{Parameter yang diamati}

Hal-hal yang diamati adalah kadar air, kandungan capsaicin, susut bobot, dan perubahan warna. Warna ditentukan dengan menggunakan spektofotometer. Cabai yang sudah dihaluskan sebanyak 70-100 mg diencerkan dengan aseton menjadi $100 \mathrm{ml}$, lalu diaduk kemudian dibiarkan selama 5 menit. Bahan diambil $(10 \mathrm{ml})$ dan diencerkan lagi. Nilai warna ditentukan dengan persamaan $\frac{\text { Ax } 164}{\text { sampel }}$, dengan A adalah absorbansi larutan pada panjang gelombang $460 \mathrm{~nm}$.

\section{Analisis Data \\ Data dianalisis dengan menggunakan metode desktiptif dan data disajikan dalam bentuk Tabel dan Gambar.}

\section{HASIL DAN PEMBAHASAN}

Suhu penyimpanan terdiri dari suhu ruang $28-32{ }^{\circ} \mathrm{C}(64-77 \%)(\mathrm{B} 1)$, Suhu $4-$ $10^{\circ} \mathrm{C}(90-95 \%)(\mathrm{B} 2)$, suhu $4-(-22)^{\circ} \mathrm{C}(95$ - 98\%) (B3), dan $-10^{\circ} \mathrm{C}$ (99\%) (B4). Setiap suhu penyimpanan menunjukan adanya perbedaan yang mengarah pada mutu cabai rawit yang harus dipertahankan. 


\section{Kadar Air}

Hasil pengukuran terhadap kadar air cabai rawit selama peyimpanan dapat dilihat pada Tabel 2. Rata-rata kadar air pada tempat penyimpanan dengan suhu $28-32{ }^{\circ} \mathrm{C}$ $(64-77 \%$ ) dan 3 tingkat kematangan yaitu matang hijau (A1), matang hijau kemerahan (A2) dan matang merah (A3) mengalami penurunan. Rata-rata kadar air A1B1 $(79,17$ $\%-78,00 \%)$, A2B1 $(80,67 \%-79,33 \%)$, A3B1 $(82,00 \%-80,67 \%)$. Hal ini disebabkan karena adanya peningkatan suhu serta penurunan kelembaban pada ruang simpan sehingga terjadi peningkatan laju penguraian cadangan makanan, akibatnya terjadi kehilangan kandungan air. Suhu yang tinggi dan kelembaban yang rendah dapat mempercepat proses respirasi produk dan menyebabkan makin cepatnya kehilangan kandungan air dan energi. Aliran udara pada permukaan bahan juga merupakan salah satu faktor yang mempengaruhi kecepatan kehilangan air. Selain itu perbedaan tekanan juga dapat mempengaruhi kehilangan air pada produk karena uap air meningkat dengan cepat pada tekanan udara yang tinggi (Utama et al, 2002). Kehilangan kadar air terjadi juga pada tepat penyimpanan dengan suhu $4-10^{\circ}$ $\mathrm{C}$, RH 90 - $95 \%$ (B2) pada tingkat kematangan matang merah (A3) yakni dari $83,17 \%$ menjadi $81,17 \%$.

Tabel 2. Rata-Rata Kadar Air Cabai Rawit Selama Penyimpanan (\%) Hari

\begin{tabular}{ccccccc}
\hline \multicolumn{7}{c}{ Hari } \\
\hline Sampel & $\mathrm{ke}-0$ & $\mathrm{ke}-6$ & $\mathrm{ke}-12$ & $\mathrm{ke}-18$ & $\mathrm{ke}-24$ & $\mathrm{ke}-30$ \\
A1BI & 79,17 & 78,00 & - & - & - & - \\
A2B1 & 80,67 & 79,33 & - & - & - & - \\
A3B1 & 82,00 & 80,67 & - & - & - & - \\
A1B2 & 80,00 & 80,17 & 80,33 & 81,67 & 82,00 & 82,67 \\
A2B2 & 80,00 & 80,33 & 80,67 & 81,67 & 82,33 & 83,00 \\
A3B2 & 83,17 & 83,00 & 82,67 & 82,33 & 81,67 & 81,17 \\
A1B3 & 78,17 & 79,00 & 80,17 & 82,67 & 83,00 & 84,33 \\
A2B3 & 81,00 & 81,68 & 82,33 & 83,00 & 83,67 & 84,33 \\
A3B3 & 84,17 & 84,68 & 85,33 & 86,00 & 86,67 & 87,33 \\
A1B4 & 78,00 & 81,33 & 82,67 & 84,33 & 85,00 & 85,17 \\
A2B4 & 81,33 & 83,17 & 84,00 & 85,33 & 86,00 & 86,67 \\
A3B4 & 84,00 & 86,17 & 87,33 & 88,67 & 89,00 & 90,33 \\
\hline
\end{tabular}

Keterangan

: tidak ada pengukuran kadar air karena cabai rawit telah mengalami penurunan mutu (pembusukan )

A1B1 : matang hijau (dipanen $45 \mathrm{HST})$ pada penyimpanan suhu ruang $28-32{ }^{\circ} \mathrm{C}(64-77 \%)$

A2B1 : matang hijau kemerahan (dipanen $55 \mathrm{HST}$ ) pada penyimpanan suhu ruang $28-32{ }^{\circ} \mathrm{C}(64-77 \%)$

A3B1 : matang merah (dipanen $65 \mathrm{HST}$ ) pada penyimpanan suhu ruang $28-32^{\circ} \mathrm{C}(64-77 \%)$

A1B2: matang hijau (dipanen $45 \mathrm{HST}$ ) pada penyimpanan Suhu $4-10^{\circ} \mathrm{C}(90-95 \%)$

A2B2: matang hijau kemerahan(dipanen $55 \mathrm{HST})$ pada penyimpanan Suhu $4-10^{\circ} \mathrm{C}(90-95 \%)$

A3B2: matang merah (dipanen $65 \mathrm{HST})$ pada penyimpanan Suhu $4-10^{\circ} \mathrm{C}(90-95 \%)$

A1B3: matang hijau (dipanen $45 \mathrm{HST})$ pada penyimpanan suhu $4-(-22)^{\circ} \mathrm{C}(95-98 \%)$

A2B3: matang hijau kemerahan (dipanen $55 \mathrm{HST}$ ) pada penyimpanan suhu $4-(-22)^{\circ} \mathrm{C}(95-98 \%)$

A3B3: matang merah (dipanen $65 \mathrm{HST})$ pada penyimpanan suhu $4-(-22)^{\circ} \mathrm{C}(95-98 \%)$

A1B4: matang hijau (dipanen $45 \mathrm{HST}$ ) pada penyimpanan $-10^{\circ} \mathrm{C}(99 \%)$

A2B4: matang hijau kemerahan (dipanen 55 HST) pada penyimpanan $-10^{\circ} \mathrm{C}(99 \%)$

A3B4: matang merah (dipanen $65 \mathrm{HST})$ pada penyimpanan $-10^{\circ} \mathrm{C}(99 \%)$ 
Penyimpanan cabai rawit pada suhu 4 - (-22) ${ }^{\circ} \mathrm{C} \quad(95$ - $98 \%)$ mengalami penambahan kadar air yakni A1B3 $(78,17 \%$ $84,33 \%)$, A2B3 $(81,00 \%-84,33 \%)$, A3B3 $(84,17 \%-87,33 \%)$ dan juga penyimpanan pada suhu - 10 dan RH 99\% terjadi pula penambahan kadar air yakni A1B4 $(78,00 \%$ $85,17 \%)$, A2B4 (81,33\% - 86,67\%), dan A3B4 (84, $00 \%-90,33 \%)$. Penambahan kadar air ini disebabkan karena adanya perbedaan tekanan uap air antara cabai rawit dengan tempat penyimpanan, dimana tekanan uap air pada produk lebih besar dibandingkan dengan tekanan uap air pada tempat penyimpanan, akibatnya uap air pada temapat penyimpanan masuk ke dalam produk. Utama et al (2002), mengunkapkan bahwa tekanan uap air bergerak dari konsentrasi tinggi ke konsentrasi rendah.

\section{Bobot}

Penurunan bobot tertinggi terjadi pada tempat penyimpanan dengan suhu 28 $32{ }^{\circ} \mathrm{C}(64-77 \%)$, pada tiga tingkat kematangan yaitu matang hijau (A1), matang hijau kemerahan (A2), dan matang merah
(A3) yakni : A1B1 $(100,00-84,17 \%)$, A2B1 $(100,00 \%-87,50 \%)$, dan A3B1 ( $100,00-88,34 \%$ ) (Tabel 2). Hal ini sesuai dengan yang diungkapkan oleh Sri et al (2012) bahwa rerata susut berat tertinggi pada penyimpanan dengan suhu kamar diperoleh pada cabai rawit yang telah mengalami masa simpan 9 hari $(64,55 \%)$, selanjutnya Rani et al (2009) menyatakan bahwa setelah penyimpanan, susut berat tertinggi yaitu terdapat pada penyimpanan suhu $29^{\circ} \mathrm{C}$ (suhu kamar) selama 15 hari yaitu $60,5 \%$ dan susut berat terendah yaitu $0 \%$ (kontrol).

Peningkatan suhu penyimpanan menyebabkan proses transpirasi semakin meningkat dimana cabai rawit mengalami penguapan cukup besar sehingga laju kehilangan air dan susut berat meningkat. Tranggono \& Sutardi (1989) mengemukakan bahwa kehilangan air mengakibatkan susut berat sehingga kualitasnya menjadi rendah. Penurunan bobot juga terjadi pada tingkat kematangan matang merah (A3) yang disimpan pada tempat penyimpanan dengan suhu $4-10^{\circ} \mathrm{C}$ dan RH $90-95 \%$ (B2) yakni A3B2 $(100,00-86,67 \%)$.

Tabel 3. Rata-Rata Bobot Cabai Rawit Selama Penyimpanan (\%)

\begin{tabular}{lllllll}
\hline \multicolumn{7}{c}{ Hari } \\
\hline Sampel & Ke-0 & ke -6 & ke -12 & ke -18 & ke -24 & ke - 30 \\
\hline A1B1 & 100 & 84,17 & - & - & - & - \\
A2B1 & 100 & 87,5 & - & - & - & - \\
A3B1 & 100 & 88,34 & - & - & - & - \\
A1B2 & 100 & 100 & 102,5 & 104,17 & 105,84 & 107,5 \\
A2B2 & 100 & 100 & 100,84 & 102,5 & 104,17 & 105,84 \\
A3B2 & 100 & 99,17 & 97,5 & 92,5 & 90,83 & 86,67 \\
A1B3 & 100 & 102,5 & 104,17 & 105,84 & 107,5 & 109,17 \\
A2B3 & 100 & 100,84 & 103,34 & 105 & 106,67 & 108,34 \\
A3B3 & 100 & 100 & 102,5 & 104,17 & 105,84 & 107,5 \\
A1B4 & 100 & 104,17 & 104,17 & 105,84 & 108,33 & 110 \\
A2B4 & 100 & 103,33 & 105 & 105,84 & 107,5 & 109,17 \\
A3B4 & 100 & 102,5 & 104,17 & 105,84 & 107,5 & 109,17 \\
\hline
\end{tabular}


Tempat penyimpanan dengan suhu 4 $-(-22)^{\circ} \mathrm{C}(95-98 \%)$ serta $-10(99 \%)$ pada tingkat kematangan matang muda (A1), matang hijau kemerahan (A2), matang merah (A3) yakni A1B3 $(100,00-109,17 \%)$, A2B3 ( 100,00 - 108,34\%), A3B3 (100,00 - 107,50 $\%)$, A1B4 $(100,00-110,00 \%)$, A2B4 ( $100,00-109,17 \%)$, A3B4 (100,00 $109,17 \%$ ) mengalami penambahan bobot. Penambahan bobot ini terjadi karena adanya penambahan uap air pada cabai rawit yang disebabkan oleh adanya perbedaan kelembaban yang mengakibatkan terjadinya perbedaan tekanan antara cabai rawit dan tempat penyimpanan. Semakin banyak uap air yang masuk ke cabai rawit maka bobot cabai rawit semakin bertambah dan akan semakin peka terhadap kerusakan. Hal ini sesuai dengan yang diungkapkan oleh Apandi (1984), bahwa kelembaban yang tinggi menyebabkan berat bahan bertambah.

\section{Capsaicin}

Tabel. 4 menunjukan bahwa pada tempat penyimpanan dengan suhu $28-32^{\circ} \mathrm{C}$ $(64-77 \%)$, dan tiga tingkat kematangan yaitu matang muda (A1), matang hijau kemerahan (A2), matang merah (A3) mengalami penurunan, A1B1 $(14,91 \%$ $14,89 \%)$, A2B1 $(14,79 \%-14,65 \%)$, A3B1 $(15,27 \%$ - 15,26\%). Penurunan kadar capsaicin juga terjadi pada tempat penyimpanan dengan suhu $4-(-22)^{\circ} \mathrm{C}(95-$ $98 \%)$ serta $-10^{\circ} \mathrm{C}(99 \%)$ pada tingkat kematangan matang muda (A1), matang hijau kemerahan (A2), matang merah (A3) yakni A1B3 $(16,02 \%-15,24 \%)$, A2B3 $(16,07 \%$ $14,91 \%)$, A3B3 $(16,63 \%-14,01 \%)$ dan A1B4 $(15,99 \%-15,66 \%), \quad$ A2B $4 \quad(15,92 \%$ $14,60 \%)$, A3B4 (16,73\% - 14,46\%). Sesudah panen tidak ada penggantian, maka kehilangan substrat dan air tidak dapat diganti dan mulailah proses kemumduran (deteriorasi). Proses kemunduran ini salah satunya dapat dilihat dengan adanya penurunan kadar capsaicin. Penurunan kadar capsaicin dapat juga terjadi karena adanya perbedaan tekanan yang tinggi antara bahan dengan tempat penyimpanan sehingga mengakibatkan kerusakan pada jaringan yang menyusun cabai rawit akibatnya terjadi kemunduran dan zat-zat yang terdapat di dalamnya berkurang. Hal ini sesuai dengan yang diungkapkan oleh Tranggono dan Sutardi (1989) bahwa susut pascapanen dapat dibedakan atas tiga kategori yaitu susut fisik, yang dapat diukur dengan berat, susut kualitas karena adanya perubahan kenampakan, cita rasa, tekstur dan warna yang menyebabkan menjadi kurang disukai oleh konsumen serta susut nilai gizi yaitu terjadi perubahan pada kandungan zat gizi.

Pada tempat penyimpanan dengan suhu $4-10^{\circ} \mathrm{C}$, RH $90-95 \%$ (B2) dan tingkat kematangan matang merah (A3) mengalami penurunan. Penurunan ini dikarenakan pada keadaan tersebut respirasi diperlambat sehingga sampai pada hari ke 30 cabai rawit mengalami proses kemunduran. Cabai mengandung kurang lebih 1,5\% (biasanya antara $0,1-1 \%$ ) rasa pedas. Rasa pedas tersebut terutama disebabkan oleh kandungan capsaicin dan dihidrocapsaicin. Kandungan homocapsaicin dan homodihidro capsaicin terdapat dalam konsentrasi sangat kecil (Santika, 2007). Kadar capsaicin akan berkurang seiring dengan terjadinya proses kemunduran yang menuju pada penuaan. Komara (1991) pada Langi (2000) menyebutkan bahwa capsaicin pada cabai akan diproduksi secara nyata pada 20 hari setelah pembungaan. Produksi ini akan terus meningkat dan mencapai maksimal pada 30 40 hari setelah pembungaan. Setelah periode tersebut capsaicin dalam cabai menurun. 
Tabel 4. Rata-Rata Capsaicin Selama Penyimpanan (\%)

\begin{tabular}{lllllll}
\hline & \multicolumn{7}{c}{ Hari } \\
\cline { 2 - 7 } Sampel & Ke-O & ke -6 & ke -12 & ke -18 & ke -24 & ke - 30 \\
\hline A1B1 & 14,91 & 14,89 & - & - & - & - \\
A2B1 & 14,79 & 14,65 & - & - & - & - \\
A3B1 & 15,27 & 15,26 & - & - & - & - \\
A1B2 & 14,33 & 14,43 & 14,98 & 15,33 & 16,11 & 16,95 \\
A2B2 & 14,53 & 14,64 & 14,96 & 15,26 & 15,81 & 16,26 \\
A3B2 & 16,09 & 15,74 & 15,72 & 15,68 & 14,89 & 13,86 \\
A1B3 & 16,02 & 15,88 & 15,66 & 15,57 & 15,27 & 15,24 \\
A2B3 & 16,07 & 15,78 & 15,7 & 15,28 & 14,91 & 14,91 \\
A3B3 & 16,64 & 15,79 & 15,32 & 15,27 & 14,65 & 14,01 \\
A1B4 & 15,99 & 15,83 & 15,83 & 15,73 & 15,71 & 15,66 \\
A2B4 & 15,92 & 15,15 & 14,96 & 14,89 & 14,65 & 14,6 \\
A3B4 & 16,73 & 16,13 & 15,56 & 15,17 & 14,79 & 14,46 \\
\hline
\end{tabular}

Tabel 5. Rata-Rata Pengujian Warna Dengan Spektrofotometer Pada Cabai Rawit Selama Penyimpanan (nano meter).

\begin{tabular}{lllllll}
\hline & \multicolumn{6}{c}{ Hari } \\
\cline { 2 - 7 } Sampel & $\mathrm{ke}-0$ & $\mathrm{ke}-6$ & $\mathrm{ke}-12$ & $\mathrm{ke}-18$ & $\mathrm{ke}-24$ & $\mathrm{ke}-30$ \\
\hline A1BI & 686 & 682 & - & - & - & - \\
A2B1 & 425 & 407 & - & - & - & - \\
A3B1 & 499 & 493 & - & - & - & - \\
A1B2 & 685 & 684 & 684 & 682 & 403 & 401 \\
A2B2 & 405 & 407 & 406 & 409 & 485 & 487 \\
A3B2 & 491 & 492 & 492 & 493 & 493 & 497 \\
A1B3 & 697 & 695 & 695 & 692 & 685 & 682 \\
A2B3 & 434 & 434 & 428 & 428 & 426 & 425 \\
A3B3 & 498 & 499 & 497 & 495 & 493 & 491 \\
A1B4 & 698 & 696 & 693 & 691 & 684 & 681 \\
A2B4 & 432 & 432 & 430 & 425 & 422 & 405 \\
A3B4 & 498 & 495 & 493 & 491 & 491 & 492 \\
\hline
\end{tabular}

Rata-rata kadar capsaicin pada tempat penyimpanan dengan suhu $4-10^{\circ} \mathrm{C}$, RH $90-95 \%$ (B2) pada tingkat kematangan matang hijau (A1), matang hijau kemerahan (A2) mengalami peningkatan yakni A1B2 $(14,333 \%-16,945 \%)$, A2B2 $(14,533 \%$ $16,260 \%)$. Kadar capsaicin bertambah seiring dengan meningkatnya tingkat kematangan.

\section{Warna \\ Pengujian dengan Spektofotometer}

Perubahan yang paling mencolok terjadi pada perlakuan A1B2, dimana terjadi perubahan panjang gelombang yang menunjukan adanya perubahan warna dari $685 \mathrm{~nm}$ pada hari ke-0 berubah menjadi 401 nm pada hari ke-30. 
Warna dan panjang gelombang $(\lambda)$ menurut Sudarmadji et al (1997) adalah :

- $400-435$ : hijau kekuningan

- $435-480$ : kuning

- $480-490$ : jingga

- $490-500$ : merah

- $500-560$ : ungu kemerahan

- $560-595$ : ungu

- $595-610$ : biru kehijauan

- $610-680$ : hijau kebiruan

- $680-700$ : hijau

Sebagian besar pigmen ini mengalami perubahan selama penyimpanan. Warna kuning, orange atau merah disebabkan oleh pigmen karoteniod. Lannes et al (2007) menyatakan bahwa pada saat buah cabai matang, terjadi sintesis pigmen karotenoid, terutama capsanthin, capsorubin, dan cryptocapsin. Perubahan warna merupakan perubahan yang paling menonjol pada waktu pematangan, seperti pembentukan karotenoid perombakan klorofil dan antosianin. Konsumen lebih menyukai cabai yang buahnya berwarna merah cerah (Lannes et $a l, 2007)$ dan buahnya kecil tetapi pedas (Sota, 2013). Penurunan suhu penyimpanan dapat menghambat pematangan cabai rawit.

Penurunan suhu pada komoditas nonklimatrik jelas menurunkan laju kerusakan sedangkan pada buah - buahan klimatrik suhu rendah juga dapat digunakan untuk menunda permulaan proses pematangan. Penurunan suhu menurunkan tidak hanya produksi etilen namun juga kecepatan respon jaringan terhadap etilen sehingga pada suhu tertentu etilen diperlukan untuk memulai pematangan (Tranggono \& Sutardi, 1989).

\section{KESIMPULAN}

Mutu cabai rawit dapat dipertahankan selama penyimpanan (30 hari) pada tingkat kematangan matang hijau (dipanen 45 HST) dan matang hijau kemerahan (dipanen 55 HST) pada suhu dan kelembaban $4-10^{\circ} \mathrm{C}(90-95 \%)$. Mutu cabai rawit tidak dapat dipertahankan lebih dari 12 hari pada penyimpanan suhu dan kelembaban $28-32 \circ \mathrm{C}(64-77 \%)$. Perlakuan pengemasan dengan plastik polyetilen dapat mempertahankan mutu cabai rawit selama penyimpanan.

\section{DAFTAR PUSTAKA}

Apandi M. 1984. Teknologi Buah dan Sayur. Alumni. Bandung.

Asgar, A. 2009. Penanganan pascapanen beberapa jenis sayuran. Makalah Linkages ACIAR-SADI. Balai Penelitian Tanaman Sayuran, Lembang. $15 \mathrm{hlm}$.

Cahyono B. 2003. Cabai Rawit. Kanisius. Yogyakarta.

Djumali M dan Sailah I. 2005. Pengantar Teknologi Pertanian. Penebar Swadaya. Jakarta

Endjang S dan M Dianawati. 2015. Produksi panen berbagai varietas unggul baru cabai rawit (Capsicum frutescens) di lahan kering Kabupaten Garut, Jawa Barat. Pros Sem Nas Masy Biodiv Indon Volume I, Nomor (4): 874-877.

Estiasai T dan Ahmadi K. 2009. Teknologi Pengolahan Pangan. Bumi Aksara. Jakarta

Kouassi CK, Koffi-nevry R, Guillaume LY et al. 2012. Profiles of bioactive compounds of some pepper fruit (Capsicum L.) Varieties grown in Côte d'ivoire. Innovative Romanian Food Biotechnol 11: 23-31.

Lannes SD, FL Finger, AR Schuelter, VWD Casali. 2007. Growth and quality of Brazilian accessions of Capsicum chinense fruits. Sci Hort 112: 266-270

Langi M T. 2000. Ekstraksi dan Karakteristik Oleoresin Cabai Rawit. [Tesis yang tidak dipublikasikan. Program Pasca Sarjana UNSRAT. Manado]

Pandeirot. B. 2003. Analisis Kehilangan Air Karena Transpirasi Pada Penyimpanan Wortel._[Skripsi yang tidak dipublikasikan UNSRAT. Manado]

Rani R, MR Defiani, NL Suriani. 2009. Pengaruh Suhu dan Lama Penyimpanan Terhadap Kandungan Vitamin C Pada Cabai Rawit Putih (Capsicum frustescens L). Jurnal Biologi Vo l u $\mathrm{m}$ e XIII, Nomor.2 :36-40. 
Rawung H. 2002. Karakteristik Pengeringan Cabe Menggunakan Alat Pengering Tipe Konveksi Bebas. [Tesis yang tidak dipublikasikan. Program Pasca Sarjana UNSRAT. Manado]

Santika A, 2007. Agribisnis Cabai. Penebar Swadaya, Jakarta.

Sota Y. 2013. Use of Capsicum frutescens in Weno, Romanum, and Piis Islands, Chuuk Atoll, Federated States of Micronesia. Occasional Papers 53: 7789.

Sri W, Y Bey dan KD Tindaon. 2012. Pengaruh Jenis Bahan Pengemas dan Lama Penyimpanan Terhadap Kadar Vitamin C dan Susut Berat Cabai Rawit (Capsicum frutescens L.). Jurnal Biogenesis, Vol. 8 , Nomor 2 : 23-30.
Sudarmadji S, B Haryono, Suhardi. 1997. Prosedur Analisa Untuk Bahan Makanan dan Pertanian (Edisi Keempat). Liberty. Yogyakarta. Syarief R dan Halid H. 1992. Teknologi Penyimpanan Pangan. Arcan. Bogor.

Tranggono dan Sutardi. 1989. Biokimia dan Teknologi Pascapanen. Pusat antar universitas Pangan dan Gizi. Universitas Gadjah Mada. Yogyakarta.

Utama S M I, Perman M G D I, dan Gucker W J. 2002. Teknologi Pascapanen Hortikultura. Program Studi Teknologi Pertanian Universitas Udayana Denpasar. Bali. 